\title{
Animal models closer to intrauterine adhesive pathology
}

\author{
Sung Woo Kim, Yoon Young Kim, Hoon Kim, Seung-Yup Ku \\ Department of Obstetrics and Gynecology, Seoul National University Hospital, Seoul, South Korea \\ Correspondence to: Seung-Yup Ku, MD, PhD. Department of Obstetrics and Gynecology, Seoul National University Hospital, Seoul, South Korea. \\ Email: jyhsyk@snu.ac.kr. \\ Comment on: Feng Q, Gao B, Zhao X, et al. Establishment of an animal model of intrauterine adhesions after surgical abortion and curettage in \\ pregnant rats. Ann Transl Med 2020;8:56.
}

Submitted Apr 28, 2020. Accepted for publication Jun 05, 2020.

doi: 10.21037/atm-20-3598

View this article at: http://dx.doi.org/10.21037/atm-20-3598

Although the true incidence of intrauterine adhesion (IUA) is uncertain, the prevalence of IUA after curettage is reported to be between $15 \%$ and $40 \%$ (1). IUA may cause menstrual disorders as well as adverse reproductive outcomes such as subfertility, infertility and recurrent miscarriage. Among the aforementioned, IUA was found in $4.6 \%$ of infertile women, and $21.8 \%$ in those with recurrent pregnancy loss $(2,3)$. Endometrial factor is much more difficult to treat than other infertility factors such as anovulation, and tubal and male factors.

Currently the treatment of choice for IUA is mainly mechanical removal of fibrotic and damaged endometrial tissue using hysteroscopic surgery. Such procedure may provide restoration of anatomical structure without the functional recovery, which leads to limited efficacy in the treatment of infertility caused by repeated embryonic implantation failure. Therefore, development of novel strategies such as the use of biological scaffolds and stem cell therapies are necessary for the treatment of refractory damaged endometrium. However, trials of various potential therapies may raise safety issues when clinically applied. It is also difficult to compare the therapeutic effects among various experimental approaches due to the lack of standardized assessment scales in currently available animal models (Table 1). Hence, the establishment of more compatible animal model to human disease is an essential component of translational research on the recovery of endometrial damage after cell therapy with or without scaffold material (22).

Recently, Xu et al. reported a successful establishment of IUA animal model which used pregnant rats. To date, animal models of IUA have been developed using various methods including chemical and/or mechanical injury in non-pregnant animals. The most important cause of IUA seems to be postpartum curettage due to their relationship with this procedure (24). The timing of endometrial trauma in relation to puerperium is considered as one of the most important factors, and this corresponds to the fact that endometrium is recovered within 3 days after curettage in non-pregnant rat models because the hormonal changes associated with pregnancy play a role in inhibiting the regeneration of epithelial cells and promoting fibrosis of interstitial tissue. Therefore, the animal model simulating human IUA using pregnant rats has a great advantage in terms of the similarity of actual pathophysiology of IUA clinically observed.

When establishing IUA animal model in pregnant rats, the procedure of removing multiple embryos in bilateral uterus is added. The shorter the duration of anesthesia is, the better stability and efficiency was shown in production of an IUA animal model (4). Therefore, it would be informative to evaluate how much time was spent by carrying out the procedure of incision, removing embryos and curettage. Also, mechanical methods using curettage were found to show inconsistent degree of damage compared to chemical methods. In this regard, it is necessary to standardize the most efficient protocol of establishing animal models.

Conclusively, since a recent study described a successful establishment of novel IUA animal model, promising results can be expected in regard to the development of more efficient strategy using this animal model. 


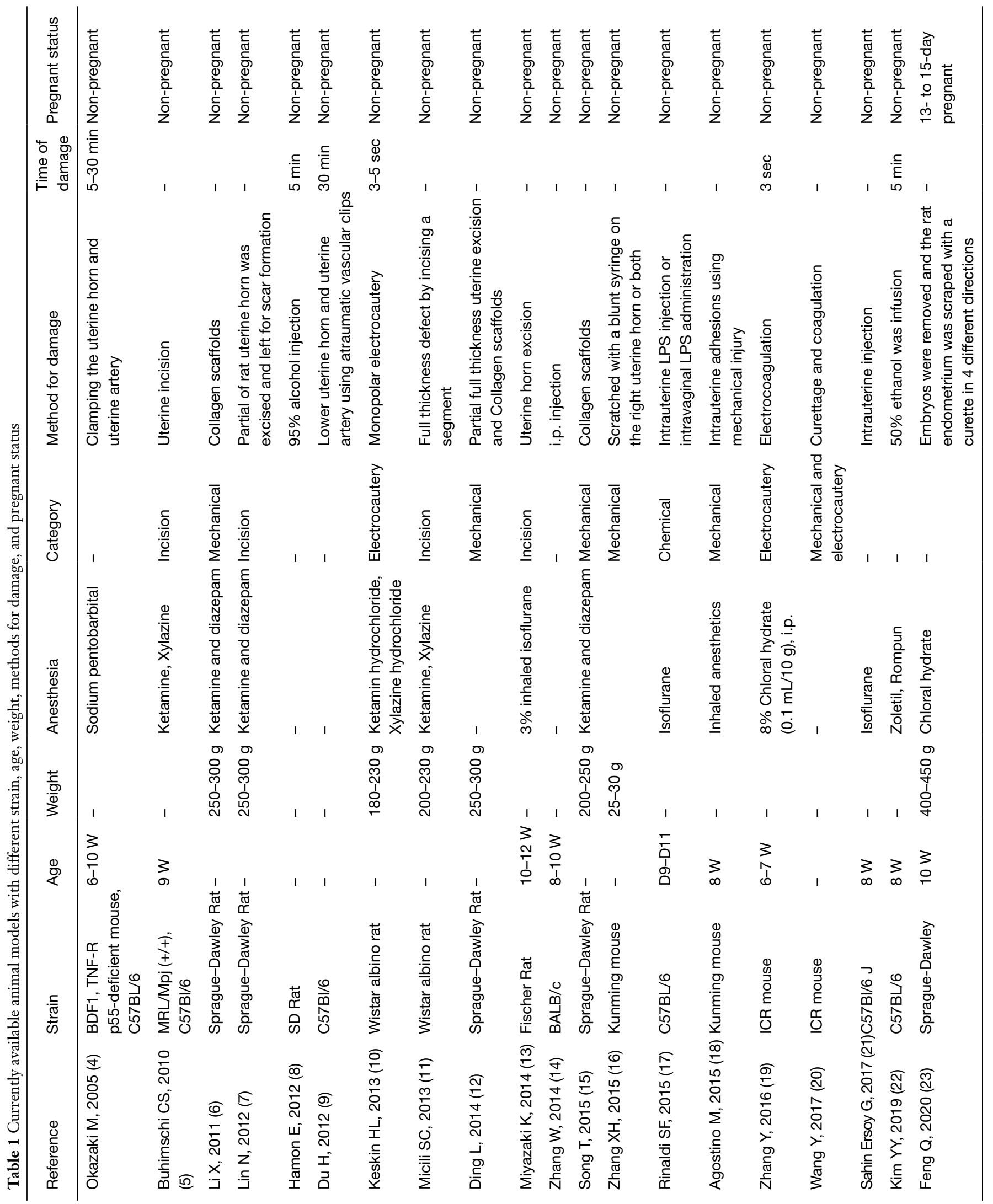




\section{Acknowledgments}

Funding: None.

\section{Footnote}

Provenance and Peer Review: This article was commissioned by the editorial office, Annals of Translational Medicine. The article did not undergo external peer review.

Conflicts of Interest: All authors have completed the ICMJE uniform disclosure form (available at http://dx.doi. org/10.21037/atm-20-3598). The authors have no conflicts of interest to declare.

Ethical Statement: The authors are accountable for all aspects of the work in ensuring that questions related to the accuracy or integrity of any part of the work are appropriately investigated and resolved.

Open Access Statement: This is an Open Access article distributed in accordance with the Creative Commons Attribution-NonCommercial-NoDerivs 4.0 International License (CC BY-NC-ND 4.0), which permits the noncommercial replication and distribution of the article with the strict proviso that no changes or edits are made and the original work is properly cited (including links to both the formal publication through the relevant DOI and the license). See: https://creativecommons.org/licenses/by-nc-nd/4.0/.

\section{References}

1. Salzani A, Yela DA, Gabiatti JRE, et al. Prevalence of uterine synechia after abortion evacuation curettage. Sao Paulo Med J 2007;125:261-4.

2. Baradwan S, Baradwan A, Al-Jaroudi D. The association between menstrual cycle pattern and hysteroscopic march classification with endometrial thickness among infertile women with Asherman syndrome. Medicine (Baltimore) 2018;97:e11314.

3. Ventolini G, Zhang M, Gruber J. Hysteroscopy in the evaluation of patients with recurrent pregnancy loss: a cohort study in a primary care population. Surg Endosc 2004;18:1782-4.

4. Okazaki M, Matsuyama T, Kohno T, et al. Induction of epithelial cell apoptosis in the uterus by a mouse uterine ischemia-reperfusion model: possible involvement of tumor necrosis factor-alpha. Biol Reprod 2005;72:1282-8.
5. Buhimschi CS, Zhao G, Sora N, et al. Myometrial wound healing post-Cesarean delivery in the MRL/MpJ mouse model of uterine scarring. Am J Pathol 2010;177:197-207.

6. Li X, Sun H, Lin N, et al. Regeneration of uterine horns in rats by collagen scaffolds loaded with collagen-binding human basic fibroblast growth factor. Biomaterials 2011;32:8172-81.

7. Lin N, Li X, Song T, et al. The effect of collagen-binding vascular endothelial growth factor on the remodeling of scarred rat uterus following full-thickness injury. Biomaterials 2012;33:1801-7.

8. Hamon E, Horvatovich P, Bisch M, et al. Investigation of biomarkers of bile tolerance in Lactobacillus casei using comparative proteomics. J Proteome Res 2012;11:109-18.

9. Du H, Naqvi H, Taylor HS. Ischemia/reperfusion injury promotes and granulocyte-colony stimulating factor inhibits migration of bone marrow-derived stem cells to endometrium. Stem Cells Dev 2012;21:3324-31.

10. Keskin HL, Sirin YS, Keles H, et al. The aromatase inhibitor letrozole reduces adhesion formation after intraperitoneal surgery in a rat uterine horn model. Eur J Obstet Gynecol Reprod Biol 2013;167:199-204.

11. Micili SC, Goker A, Sayin O, et al. The effect of lipoic acid on wound healing in a full thickness uterine injury model in rats. J Mol Histol 2013;44:339-45.

12. Ding L, Li X, Sun H, et al. Transplantation of bone marrow mesenchymal stem cells on collagen scaffolds for the functional regeneration of injured rat uterus. Biomaterials 2014;35:4888-900.

13. Miyazaki K, Maruyama T. Partial regeneration and reconstruction of the rat uterus through recellularization of a decellularized uterine matrix. Biomaterials 2014;35:8791-800.

14. Zhang W, Zhang N, Wang W, et al. Efficacy of cefepime, ertapenem and norfloxacin against leptospirosis and for the clearance of pathogens in a hamster model. Microb Pathog 2014;77:78-83.

15. Song T, Zhao X, Sun H, et al. Regeneration of uterine horns in rats using collagen scaffolds loaded with human embryonic stem cell-derived endometrium-like cells. Tissue Eng Part A 2015;21:353-61.

16. Zhang XH, Liu ZZ, Tang MX, et al. Morphological changes and expression of cytokine after local endometrial injury in a mouse model. Reprod Sci 2015;22:1377-86.

17. Rinaldi SF, Makieva S, Frew L, et al. Ultrasoundguided intrauterine injection of lipopolysaccharide as a novel model of preterm birth in the mouse. Am J Pathol 2015;185:1201-6. 
18. Agostino M, Velkov T, Dingjan T, et al. The carbohydratebinding promiscuity of Euonymus europaeus lectin is predicted to involve a single binding site. Glycobiology 2015;25:101-14.

19. Zhang Y, Lin X, Dai Y, et al. Endometrial stem cells repair injured endometrium and induce angiogenesis via AKT and ERK pathways. Reproduction 2016;152:389-402.

20. Wang Y, Huang Q, Sheng XU, et al. Establishment of mouse endometrial injury model by curettage or coagulation. Zhejiang Da Xue Xue Bao Yi Xue Ban 2017;46:186-91.

21. Sahin Ersoy G, Zolbin MM, Cosar E, et al. CXCL12 promotes stem cell recruitment and uterine repair after injury in asherman's syndrome. Mol Ther Methods Clin

Cite this article as: Kim SW, Kim YY, Kim H, Ku SY. Animal models closer to intrauterine adhesive pathology. Ann Transl Med 2020;8(18):1125. doi: 10.21037/atm-20-3598
Dev 2017;4:169-77.

22. Kim YY, Park KH, Kim YJ, et al. Synergistic regenerative effects of functionalized endometrial stromal cells with hyaluronic acid hydrogel in a murine model of uterine damage. Acta Biomater 2019;89:139-51.

23. Feng Q, Gao B, Zhao X, et al. Establishment of an animal model of intrauterine adhesions after surgical abortion and curettage in pregnant rats. Ann Transl Med 2020;8:56.

24. Hooker AB, de Leeuw R, van de Ven PM, et al. Prevalence of intrauterine adhesions after the application of hyaluronic acid gel after dilatation and curettage in women with at least one previous curettage: short-term outcomes of a multicenter, prospective randomized controlled trial. Fertil Steril 2017;107:1223-31.e3. 